\title{
Пролетна научна конференция: Съвременни концепции в лечението на ушите, носа и гърлото
}

Резюмета

Асоциация на лекарите по оториноларингология ИСУЛ

Л1

\section{Трахеални стенози след парциални резекции на ларинкса по повод на кар- цином на ларинкса}

Ю. Рангачев, Т. Попов, Ст. Йорданов,

М. Цекова, Д. Хунашвили, Н. Алхури,

Д. Дачев, Ив. Чалъков

Клиника УНГ-болести,

УМБАЛ „ЦЦарица Йоанна-ИСУЛ“, МУ - София

Трахеалните и ларингеалните стенози са сравнително редки усложнения при оперативни интервенции, манипулации и интубации. Стенозите, получени след парциални резекции на ларинкса при ларингеални карциноми, също не са много чести усложнения, но дори и получени, в повечето случаи са компенсирани. Трахеалните стенози, получени при пациенти с ларингеални карциноми и парциални ларингеални резекции, които са провели и радиотерапия обаче, са сравнително чести и в повечето случаи са декомпенсирани и често водят до постоперативна диспнея и влошават качеството на живот на пациентите. Представяме няколко наши клинични случая с постоперативни стенози на трахеята при пациенти с ларингеален карцином след парциална ларингеална резекция, които са получили постоперативно радиотерапия.
Ключови думи: карцином на ларинкса, парциална резекция на ларинкса, стеноза на ларинкса, стеноза на трахеята, радиотерапия

Л2

\section{Малигнени заболявания на околоносни кухини и метастази на шията. Честота и поведение}

Ю. Рангачев, Т. Попов, Ст. Йорданов,

М. Цекова, Д. Хунашвили, Н. Алхури, Д. Дачев, Ив. Ценев

УМБАЛ „Царица Йоанна-ИСУЛ“, МУ - София

Злокачествените тумори на околоносните кухини представляват около $3 \%$ от туморите на горните дихателни пътища. Най-често те са от епителен произход, но има и неепителни тумори като саркоми, меланоми, НХЛ и др. Близостта им до жизненоважни структури като мозъка, зрителните нерви, черепно-мозъчни нерви и важни кръвоносни съдове определя ранните им клинични прояви и възможността за радикалното им отстраняване. Често метастазите сьпьтстват установяването на първичните тумори, но по-често те се установяват на по-късен етап, когато пациентът вече е провел оперативно лечение, радиотерапия или химиотерапия и въз- 
можностите за оперативно лечение са ограничени. Представяме случаи от нашата клинична практика и варианти за клинично поведение.

Ключови думи: синоназален карцином, малигнен меланом, радикална шийна дисекция, лъчелечение, химиотерапия.

\section{Л3}

\section{Назофарингеален карцином в детската и младата възраст}

Д. Конов, Ст. Йорданов, Ив. Боронсузов, Ив. Щърбанов, М. Генадиева, Ю. Хаджиев, Иг. Станчева

МУ - София, Катедра по УНГ-болести, Катедра по обща и клинична патология УМБАЛ „ЦЦарииа Йоанна-ИСУЛ“ ЕАД, гр. София, Клиника по УНГ-болести СБАЛДОХЗ - ЕООД, гр. София

Малигнените тумори с първична локализация в назофаринкса са рядкост в детската възраст. Един от най-честите типове е недиференцираният назофарингеален карцином. Основният лечебен метод при тези неоплазми е лъчетерапията, която често се съчетава с химиотерапия, както и адювантна имунотерапия с бета-интерферон. Често началните прояви на болестта протичат незабелязано и диагнозата се поставя в късните стадии от развитието. Представяме няколко клинични случая от нашата практика на назофарингеални карциноми в детската възраст.

\section{Л4}

\section{Поведение и възможни усложнения при чуждо тяло в долните дихателни пътища при деца}

\section{Ц. Цолов, П. Переновска, Т. Аврамов}

Въведение: Чуждите тела в долните дихателни пътища в детска възраст представляват сериозен проблем за лекуващия екип и не рядко могат да доведат до летален изход.

Материал и метод: Авторите проследяват поведението и рисковете при лечението на 1179 деца, от които 675 с диагноза „Чуждо тяло в долните дихателни пътища“" на възраст от 0 до 3 години за периода 1995-2013 година, преминали през УНГ-клиника на УМБАЛ „Царица ЙоаннаИСУЛ“ - София и Детска клиника на УМБАЛ „Александровска“ - София, използвайки при анализа данните на Националната статистика за броя починали деца с чуждо тяло в долните дихателни пьтища.

Резултати: За проследявания период при 667 деца с чуждо тяло в долните дихателни пътища лечението е успешно приключило, като при 59 от децата се е наложила повече от една ендоскопска процедура. При 12 от децата лечението е продължило в Клиника по гръдна хирургия, поради невъзможност от ендскопска екстракция на чуждите тела от долните дихателни пътища. Заключение: Чуждите тела в долните дихателни пътища при децата, особено до 1-годишна въ3раст, са изключително коварни и опасни поради незрелостта на дихателните пътища при децата. Те изискват внимание, опит при диагностицирането им и добра колаборация между педиатри, бронхоскописти, анестезиолози с опит при работа с деца и гръден хирург, за максимално избягване на усложнения и летален изход. Ключови думи: чужди тела, поведение, усложнения, ендоскопия, долни дихателни пьтища

\section{Л5}

\section{Макрофагеална инфилтрация и пльтност на неоангиогенезата при карцином на ларинкса и тяхната корелация с процеса на метастазиране - изследване върху 52 случая}

\author{
T. Попов, Ю. Рангачев, Сn. Тодоров,
}

О. Стоянов, Д. Конов, Ив. Чальков

Ангиогенезата е един от шестте специфични белега на малигнома, която е широко изследвана през последните две декади. Целта на нашето проучване е да оценим микросьдовата и макрофагеалната пльтност в ларингеалния карцином и да потърсим клиникопатологични корелации. Чрез имунохистохимия количествено определихме микросъдовата плътност (антитела към $\mathrm{CD} 4+$ ) и макрофагеалната степен на инфилтрация (антитела към CD68+), използвайки микроарей техника. Средната съдова пльтност в изследваната група бе $14.27 \pm 12.92$ съда на х200 поле, а 
средната пльтност на макрофагеална инфилтрация бе $5.19 \pm 4.32$ на х200 поле. Средната микросъдова пльтност бе статистически значимо поголяма при пациенти с метастатичен процес в регионалните лимфни възли, спрямо тези без, при еквивалентен стадий на първичния тумор. Допълнително, линеарната регресия показа, че макрофагеалната инфилтрация корелира с нивата на ангиогенеза, което е доказателство на ролята на имунната система за формирането на съдовото русло в туморната тъкан.

\section{Л6}

\section{Шиен лимфаденит в детската възраст - рядък клиничен случай от практиката}

И. Станчева, Сn. Тодоров, Л. Попов, И. Тодоров, И. Терзиев

\section{МУ - София, Катедра по УНГ-болести}

Лимфаденитът в детската възраст е често свързан с инфекции на горните дихателни пьтища - отити, риносинуити, тонзилофарингит. Нерядко инфекциите на кожата и лигавиците, както и бактериалните и вирусните инфекции се усложняват с лимфаденит. Увеличението на лимфните възли може да е и първа изява на някои злокачествени заболявания.

Представяме клиничен случай от практиката: 14-годишно момче с шиен лимфаденит, придружен от продължителен фебрилитет - банална инфекция или рядко заболяване?

\section{Л7}

\section{Протезиране на а. каротис комунис при радикална шийна дисекция - за пьрви път в България}

\author{
К. Попов, Д. Марков, А. Тодоров
}

\section{СБАЛО - ЕАД, отделение по УНГ-болести} СОФИЯМЕД, отделение по съдова хирургия

Съвместен екип - оториноларинголог и съдови хирурзи, извърши 3 радикални шийни дисекции с протезиране на а. каротис комунис. Болните са с ларингеален карцином. Метастазите обхва- щаха циркумференцията на артерията, което обикновено е противопоказание за оперативно лечение. Описват се етапите, обсъждат се резултатите и индикациите за тази операция.

\section{Л8}

\section{Видеоендоскопска радиохирургия при кисти на Торнвалд}

\author{
Ю. Николов*, М. Николова**, П. Чапаров* \\ * УНГ отделение, \\ МБАЛ „Света Параскева“ - Плевен \\ ** Катедра по УНГ болести, МУ - София, \\ Клиника по УНГ-болести, \\ УМБАЛ „Царииа Йоанна-ИСУЛ“ ЕАД - София
}

При болестта на Торнвалд се формира кистоподобно образувание в областта на средната бразда на назофарингеалната тонзила. В последно време, благодарение на широкото разпространение и използване на ендоскопски методи за изследване на носа и носогльтката, зачестиха случаите с диагностициране на киста на Торнвалд. Разпространението ѝ достигна до $5 \%$ в популацията.

Цел: Да се обобщят и систематизират предимствата от използването на видеоендоскопска радиохирургия при операции по повод диагностицирана киста на Торнвалд.

Материал: 11 пациенти (8 жени и 3 мъже) на възраст от 28 до 60 години за период от 2 години са оперирани с помощта на видеоасистирана радиохирургична техника в нашето отделение.

Mетоди: C HFITT техника и биполярен електрод под видеоендоскопски контрол се направи радиодиструкция на предната стена на кистата, последвана от аспирация и радиофреквентна коагулация на лигавицата.

Резултати: В 10 от случаите субективните оплаквания от стичане на секрет в гърлото, главоболие, лош дъх, загльхване на ушите са изчезнали или значително намалели. В един от случаите стичането на секрет продължи, вероятно дължащо се на сьпьтстващия алергичен ринит.

Изводи: Получените положителни постоперативни резултати при киста на Торнвалд ни позволяват да съдим за ефективността на видеоендоскопската радиохирургична техника в хирур- 
гичното лечение на тази патология. Операцията се понася добре от пациентите, като не се съпровожда от болка и възпалителни промени в организма. Рецидиви след интервенцията не сме наблюдавали.

\section{P1}

\section{Мукоцеле на фронтален синус - случай от практиката}

\author{
С. Димитров, С. Тодоров, О. Стоянов, \\ И. Тодорова, Т. Аврамов, Х. Бенов, М. Николова
}

Мукоцелето е доброкачествено кистично образувание на околоносните кухини с бавен растеж, като се смята, че се формира поради обструкция на естествените синусови отверстия. Най-честата локализация е във фронталните и етмоидални синуси.

Представяме клиничен случай на мъж на 50 г., претърпял трепанация на левия фронтален синус преди 15 години. Няколко години по-късно започва да усеща периорбитален дискомфорт и диплопия. Към момента на постъпване в клиниката се установи голяма кистична формация в горната част на орбитата, екзофталм и избутване на булбуса каудално. Компютьрна томография на глава разкри голямо мукоцеле, изхождащо от левия фронтален синус. Проведе се трепанация на фронталния синус с добър резултат. 6 месеца след операцията няма данни за персистенция и рецидив на заболяването.

\section{P2}

\section{Неуспехи при функционалната ендоскопична хирургия на синусите - фактори от страна на хирургията}

\author{
Р. Бенчев, Ив. Йорданов \\ УМБАЛ ,Софиямед“"
}

Лечението на хроничния риносинуит е предимно медикаментозно и е свързано с употреба на антибиотици, кортикостероиди (системни или локални), муколитици, назални промивки и други. Често, при трудни за лечение хронични риносинуити, се налага използване и на т.нар. максимална медикаментозна терапия, която трае седмици и дори месеци. При неуспех на консервативното лечение се прилага и хирургия на околоносните кухини. През последните години в световен мащаб се наложи функционалната ендоскопична хирургия на синусите като основен оперативен подход. Целта на тази оперативна намеса е да осигури по-добро носно дишане, по-добра вентилация и дренаж на синусите и така да премахне патофизиологичните механизми за развитие на хроничния риносинуит. Въпреки хирургичната намеса, в редица случаи риносинуитът продължава да предизвиква симптоми, повлияващи качеството на живот на пациентите. Факторите, които влияят на неуспеха на хирургичното лечение, са главно два: субоптимална оперция, несъобразена с характера и тежестта на заболяването и особеностите на възпалителния процес, водещи до рецидивиране на заболяването.

В настоящата презентация е направен преглед на литературата, подкрепен със собствен опит, на най-честите причини за неуспех на ФЕСХ, свързани с недостатъците на приложената оперативна техника. Прави се извод, че основните грешки идват от недостатъчен опит на хирурга за извършване на по-радикални интервенции и несъобразяване на обема на операцията с факторите от страна на възпалението. Обсъжда се необходимостта от по-разширени оперативни намеси, извън основополагащите принципи на ФЕСХ за минимално инвазивна хирургия.

\section{P3}

\section{Неуспехи при функционалната ендоскопична хирургия на синусите - фактори от страна на възпалителния процес}

\author{
Р. Бенчев, Ив. Йорданов \\ УМБАЛ ,Софиямед“
}

Лечението на хроничния риносинуит е предимно медикаментозно и е свързано с употреба на антибиотици, кортикостероиди (системни или локални), муколитици, назални промивки и други. Често при трудни за лечение хронични риносинуити се налага използване и на т.нар. максимална медикаментозна терапия, която трае седмици и дори месеци. При неуспех на консервативното лечение се прилага и хирургия на 
околоносните кухини. През последните години в световен мащаб се наложи функционалната ендоскопична хирургия на синусите като основен оперативен подход. Целта на тази оперативна намеса е да осигури по-добро носно дишане, по-добра вентилация и дренаж на синусите и така да премахне патофизиологичните механизми за развитие на хроничния риносинуит. Въпреки хирургичната намеса, в редица случаи риносинуитьт продължава да предизвиква симптоми, повлияващи качеството на живот на пациентите. Факторите, които влияят на неуспеха на хирургичното лечение, са главно два: субоптимална оперция, несьобразена с характера и тежестта на заболяването, и особеностите на възпалителния процес, водещи до рецидивиране на заболяването.

В настоящата презентация са разгледани факторите от страна на възпалителния процес на синусите, които водят до рецидивиране на заболяването, въпреки адекватна хирургическа намеса. На базата на литературни данни и собствен опит се дискутира ролята на алергията, еозинофилното възпаление, биофилмите, персистиращия остеит и остеогенеза и начините за тяхното лечение.

\section{P4}

\section{Персистиращ дуктус тиреоглосус}

Ст. Йорданов, Д. Конов, М. Генадиева, М. Николова, М. Цекова, Т. Попов,

Ю. Рангачев, Д. Хунашвили

МУ - София, Катедра по УНГ-болести, Катедра по обща и клинична патология

\section{УМБАЛ „Царииа Йоанна-ИСУЛ“ ЕАД - София, Клиника по УНГ-болести}

Представяме три клинични случая на срединни тиреоглосални кисти на шията, оперирани в клиниката, както и методите на диагностика и лечение.

Кистите, произхождащи от ductus thyreoglossus, са най-честите конгенитални шийни кисти. Разположени са срединно на шията и се проявяват в детската и младата възраст. Методите на диагностика могат да бъдат различни, а лечението е изцяло хирургично.
P5

\section{Малигнен меланом с локализация в околоносните кухини - клиничен случай}

М. Николова*, М. Цекова-Чернополска*, Д. Качаров**, Ст. Йорданов*, Ю. Рангачев*, Ив. Ценев*

* Катедра по УНГ-болести, МУ - София, Клиника по УНГ-болести, УМБАЛ „Царииа Йоанна-ИСУЛ“ ** Спечиализирана болница за активно лечение по онкология - СБАЛО, София

Малигненият меланом е злокачествено новообразувание с произход от меланоцитите. Представлява един от най-злокачествените тумори и се характеризира с ранно метастазиране. Найчесто се развива върху кожата, а негови поредки локализации са окото (роговица, ретина) и мукозни тъкани. Melanoma malignum представлява $2-4 \%$ от всички злокачествени образувания във външния нос и околоносните кухини. Меланомът с лигавична локализация в областта на главата и шията се среща по-често при пациенти в напреднала възраст - 60-80 години, като предилекция към пола няма. Расте инфилтративно, с ранни лимфо- и хематогенни метастази. Често води началото си от полип с улцерирала повърхност и тьмнокафяво оцветяване. Клиниката се доминира от епистаксиси и затруднено носно дишане. За поставяне на диагнозата от значение са образните изследвания, имунохистохимичният анализ и типичната хистологична картина.

Представяме ви клиничен случай на малигнен меланом с локализация в максилоетмоидалния ъгъл на 89-годишен пациент. Болният съобщава за рецидивиращи епистаксиси, нарушено носно дишане и хрема с голяма давност. След направената компютьрна аксиална томография (КАТ) и установяване на туморна формация, ангажираща общ носов ход вдясно, максиларен синус, етмоидалнки клетки, проминираща към кухината на назофаринкса, пациентьт се приема за оперативно лечение - медиофациална резекция. Резултатът от патолого-хистологичното изследване дава характерната картина на малигнен меланом, поради което пациентьт се насочва за следоперативна химио- и телегаматерапия. 


\section{P6}

\section{Ендоскопски операции при полипоза на пациенти под 18 години - клиничен случай и обзор}

\author{
T. Попов, Ю. Рангачев, Сn. Тодоров, \\ О. Стоянов, Д. Конов, Ст. Йорданов
}

Болестите на детските околоносни кухини обхващат голям обхват от патологии. Рядко в медицинската литература могат да се намерят студия с добър дизайн и достатъчно голям брой пациенти от тази група. Авторите представят кратък обзор върху темата и представят клиничен случай на полипозна дегенерация на максиларния синус при 14-годишно момиче - клиника, диференциална диагноза и извършената ендоскопска оперативна интервенция.

\section{P7}

Titanium implants for the nose: A new frontier

Prof. Dr. med. Daniel F. à Wengen

\section{P8}

\section{Техники при ендоскопска ендоназална синус хирургия. Нашият опит при лечение на доброкачествени новообразувания на околоносни кухини}

\section{А. Асенов, Д. Делчев}

Отделение по УНГ-болести, МБАЛ „Пловдив“, Пловдив

Ендоскопската ендоназална хирургия е модерен, минимално инвазивен метод за лечение на редица заболявания на носа и параназалните кухини. Приложима е както при лечение на хронични синуити, така и при трудни за овладяване случаи на епистаксис, при новообразувания на нос и околоносни кухини и базата на черепа, а също и като достъп при неврохирургични операции. Наред с множеството предимства, ендоскопската ендоназална хирургия има някои ограничения, за справяне с които са разработени редица техники и достъпи. Ще бъдат представе- ни някои техники при ендоскопска ендоназална синус хирургия и два случая на ендоскопски операции при доброкачествени тумори на максиларен синус от нашата практика, при които са приложени улесняващи подходи.

\section{1}

\section{Нашият опит от едногодишното приложение на video HIT-теста}

\section{T. Широв}

МУ, Катедра УНГ-болести, болница „Царицуа Йоанна - ИСУЛ“ - София

Видео НIT-тестът (vHIT) е технологично усъвършенстване на НIT-теста, описан и въведен в практиката от Michael Halmagyi и Ian Curthuoys през 1988 год. като бърз и надежден тест за установяване на едностранен периферен вестибуларен дефицит.

Видеорегистрация с последваща обработка на запис на вестибуло-очедвигателния рефлекс (VOR-reflex) изключително много улеснява провеждането на теста и диагностицирането на периферните вестибуларни дисфункции. Нещо повече - този тест до голяма степен ограничава използването на по-неприятните за пациентите врьщателен и калоричен тест.

За 1,5-годишен срок ние сме изследвали над 390 пациенти с различен вид вертижни оплаквания. Сравнени са резултатите от този тест с данните от рутинното отоневрологично изследване и провокационните тестове. Установява се, че в резултат на рутинното приложение на този тест в ежедневната ни отоневрологична практика точността на диагностиката се повишава, а времето, необходимо за пълното изследване на един пациент, се намалява.

Разгледани са подробно техниката на изследването, предимствата му пред други подобни методи, както и нашият опит при някои трудни за диагностициране случаи. Освен ясното разграничаване на периферната от централната вестибуларна патология, този тест дава възможност за бърза оценка на функцията на всеки един от полуокръжните канали поотделно, нещо, което преди въвеждането на този тест беше невъзможно. 
$\mathbf{O 2}$

\section{Комбинирано лечение на невросензорна загуба на слуха с хипербарна оксигенация и лекарствени средства}

\author{
К. Георгиев*, Хр. Бозов*, В. Цветков**, \\ П. Куцаров*, Й. Заякова* \\ *МБАЛ - Варна, ВМА \\ **BMA - София
}

В презентацията са разгледани част от терапевтичните средства за лечение на НСЗС, като действие на рецепторно и молекулно ниво. Представени са възможни взаимодействия, водещи до търсения от лекаря ефект, както и нежелани или неочаквани интеракции между използваните лекарствени средства.

Ключови думи: невросензорна загуба на слуха, лечение, хипербарна оксигенация

\section{$\mathbf{O 3}$}

\section{Клиничен случай със} звукопроводно намаление на слуха

Д. Попова, С. Върбанова, Сп. Тодоров, И. Станчева, О. Стоянов, Т. Попов

УМБАЛ „Царииа Йоанна-ИСУЛ, Катедра по УНГ- болести “, МУ - София

Концепцията за звукопроводно намаление на слуха е предложена за първи път през 1960 г. от Gloris and Davis и по-късно от Nixon and Glorig. Те предполагат повишена ригидност на кохлеарната част на вътрешното ухо. Някои автори използват термина псевдо звукопроводно намаление на слуха. В повечето случаи диагнозата се поставя, без да се прибягва до оперативно лечение. В по-голямата си част се дължи на костни аномалии, при които е необходимо да се направи КТ с висока резолюция, и най-често се търси комуникация на основната витка на охлюва със съседните анатомични структури.
04

\section{Световъртеж и системни метаболитни нарушения}

С. Вълчева

Звуковите и вестибуларни симптоми са общи при пациенти със захарен диабет. Слуховите и вестибуларните дисфункции се появят както в преддиабетно състояние, така и с бъбречни промени. Най-важният аспект в предотвратяването на слухови и вестибуларни дисфункции при пациенти с уремия, е да се избегне използването на потенциални ототоксични вещества. Внимателното управление на електролити при пациенти, подложени на хронична бъбречна диализа, ще предотврати вариращи слухови и вестибуларни симптоми. Виене на свят може да възникне и при пациенти с хипотиреоидизъм Двустранната невросензорна загуба на слуха, свързана с придобит хипотиреоидизъм, се подобрява след подържаща терапия с хормона на щитовидната жлеза.

\section{5}

\section{Резултати от двустранната кохлеарна имплантация при деца}

\author{
Д. Попова, С. Върбанова, Сп. Тодоров,
}

И. Станчева, О. Стоянов

Медицински факултет на

Медииински университет - София

Катедра УНГ-болести

Авторите представят резултатите от извършените в УМБАЛ „Царица Йоанна“ - ИСУЛ, гр. София кохлеарни имплантации на двете уши при деца.

Отчетени се данни от развитието на 14 двустранно оперирани деца. Те са разделени на 2 групи, състоящи се от по 7 деца. Разликата между двете групи е във времето на извършване на втората имплантация - преди и след 1 година. Използвани са стандартните тестове за оценка на промяната в развитието на оперираните деца. 


\section{6}

\section{Изследване на слуха на деца между 3 и 6 години чрез ShoеBox аудиометрия}

Ал. Вълков, Ю. Тодорова, Б. Духленски, Г. Николов, Кр. Атанасова, А. Хвърчилкова

\section{УМБАЛ „Д-р Георги Странски“ - Плевен} Клиника по ушно, носно, гърлени болести

Интерактивната ShoeBox аудиометрия е нов метод за оценка прага на чуване по въздушен път. Представлява iPad - базирано приложение, чрез което пациентът контролира сам продължителността и темпото на звуковите дразнители. Има значима прогностична стойност за нормален слух и висока чувствителност за загуба на слуха. Поради своята точност, простота, бързина този метод на изследване може да се използва за масов скрининг при деца.

За период от 3 месеца в Клиниката по УНГ-болести и Клиниката по детски болести при УМБАЛ - Плевен бяха изследавани 3-, 4-, 5- и 6-годишни деца посредством ShoeBox аудиометрия. B изследваните групи бяха включени както здрави деца, така и деца с вече установено намаление на слуха. Установиха се следните предимства на метода: децата от всички възрастови групи, както и техните родители го възприемат позитивно и с интерес участват в изследването. При 5- и 6-годишните деца ShoeBox аудиометрията завършва успешно, докато 4-годишните се нуждаят от допълнителни напътствия. Във възрастовата група на 3-годишните рядко се наблюдава задържане на концентрацията и вниманието, като резултатите не могат да бъдат интерпретирани.

\section{7}

\section{Съвременни тенденции в лечението на злокачествения външен отит}

П. Руев*, А. Бачовска*, М. Михов*

*Отделение УНГ-болести, МБАЛ „Тракия“, Стара Загора

(I.) Увод: Злокачественият външен отит е инвазивна инфекция на външния слухов проход, която все още е терапевтично предизвикател- ство. Най-често заболяването засяга пациенти със захарен диабет, a Pseudomonas aeruginosa ce изолира от секрет от ухото в повече от $80 \%$ от случаите. Патофизиологията на заболяването не е напълно установена, но като потенциален ятрогенен фактор се смята иригацията на външния слухов проход с вода при промивка за церумен.

(II.) Цел на проучването: Целта на това изследване е да представим нашия опит с лечението на пациенти със злокачествен външен отит.

(III.) Материал и метод: За период от 4 години от 2012 до 2015 год. са лекувани 12 пациенти със злокачествен външен отит (средна възраст 69 год., от 49 до 85 год.; мъже 7, жени 5). Всички демографски показатели, като придружаващи заболявания, параметри на слуха, изолирани причинители, рентгенови изследвания, продължителност на хоспитализацията, лечение преди хоспитализацията и други са анализирани.

(IV.) Анализ на данните: Ретроспективен анализ на болничните хоспитализации.

(V.) Резултати: Типичният пациент със злокачествен външен отит е с оплаквания от продължителна силна болка в ухото и гнойна секреция. Парализа на лицевия нерв се наблюдава в два случая. Диагнозата злокачествен външен отит се базира на комбинацията от клинични данни, ускорено СУЕ и увеличен С-реактивен протеин (CRP), заедно с рентгенови данни за мекотьканно засягане със или без костна ерозия на външния слухов проход и инфратемпоралната ямка. Лечението включва локално почистване и продължително прилагане (от 3 до 6 седмици) на локални и системни противопсевдомонасни антимикробни средства. В три случая допълнително сме поставили T-tubes вентилиращи тръбички за 3 до 6 месеца. При един пациент се наложи допълнително хирургично лечение (мастоидектомия).

(IV.) Заключения: Злокачественият външен отит е относително рядко заболяване, което найдобре се лекува мултидисциплинарно. Найефективното лечение е контрол на диабета, от една страна, и адекватно антибиотично лечение, от друга. В нашето проучване асоциацията между локални аминогликозидни антибиотици и системно приложение на Ciprofloxacin и Clindamycine има ефект при повишаваща се по литературни данни резистентност на Р. aeruginosa към хинолоните. В някой случай инсерцията на вентилиращи T-tube за по-дъльг 
период от време е добра идея за допълнителна минимално инвазивна хирургия.

\section{8}

\section{Загуба на слуха при дефекти в текториалната мембрана}

\author{
К. Георгиев*, Хр. Бозов*, В. Цветков**, \\ П. Кучаров*, Й. Заякова* \\ *МБАЛ Варна ВМА, \\ **BMA- София
}

В настоящата презентация е разгледана membrana tectoria в норма, както и някои проучени нейни структурни и функционални дефекти и асоциираните с тях нарушения на слуха. Примерите са онагледени с илюстративен материал. Поставени са въпроси, чието решаване ще прецизира отношението ни към нарушенията на слуховата перцепция.

Ключови думи: текториална мембрана, загуба на слуха

B1

\section{Слипвидеоендоскопия - един надежден метод за диагностика на патологията на ГДП (горни дихателни пьтища) при обструктивна сьнна апнея}

\section{Ю. Николов*, П. Чапаров*, М. Николова**}

* УНГ отделение, МБАЛ „Света Параскева“,

Плевен

** Катедра по УНГ болести,

МУ - София, Клиника по УНГ-болести, УМБАЛ ,Царица Йоанна-ИСУЛ“

Обструктивните дихателни нарушения в проходимостта на ГДП (горни дихателни пьтища) в настояще време се явяват особено актуален проблем. Тази патология придобива водещо значение при проблемите с обструктивна сънна апнея, водещи до периодични нарушения от страна на сърдечносъдовата и дихателната система на организма.

Цел: Към настоящия момент основен водещ метод за диагностика на OCA (обструктивна сънна апнея) се явява комютьрната полисомнография, даваща само количествена представа за тежестта на процеса. За качествените промени в ГдП бихме могли да съдим след изследване и обобщаване на данните от предложената от нас слипвидеоендоскопия, което се явява цел на настоящата презентация.

Материал: СВЕ (слипвидеоендоскопия) се направи при 25 пациенти със сънна апнея - 21 мъже и 4 жени на възраст от 34 до 60 години.

Метод: След проведена компютърна полисомнография под венозна анестезия с помощта на флексибилна ендоскопска техника „Олимпус“ се направи видеоендоскопия на ГДП.

Резултати: Като се анализира нивото на обструкцията, продължителността на епизодите от апнея и хипопнея, се направи преценка за ефективността от евентуална бъдеща хирургична интервенция.

Извод: Като отчитаме простотата на метода за диагностика, неголемите изисквания към оборудването и високата му информативност, ние го препорьчваме за допълнителна диагностика на ССА (синдром на обструктивна сънна апнея).

B2

\section{Малигнен меланом с локализация в околоносните кухини - клиничен случай}

М. Николова*, М. Цекова-Чернополска*, Д. Качаров**, Ст. Йорданов*, Ю. Рангачев*, Ив. Ценев*

* Катедра по УНГ-болести, МУ - София, Клиника по УНГ-болести, УМБАЛ „Царииа Йоанна-ИСУЛ“

** Специализирана болница за активно лечение по онкология - СБАЛО, София

Малигненият меланом е злокачествено новообразувание с произход от меланоцитите. Представлява един от най-злокачествените тумори и се характеризира с ранно метастазиране. Найчесто се развива върху кожата, а негови по-редки локализации са окото (роговица, ретина) и мукозни тькани. Melanoma malignum представлява $2-4 \%$ от всички злокачествени образувания във външния нос и околоносните кухини. Меланомът с лигавична локализация в областта на главата и шията се среща по-често при пациенти в напред- 
нала възраст - 60-80 години, като предилекция към пола няма. Расте инфилтративно, с ранни лимфо- и хематогенни метастази. Често води началото си от полип с улцерирала повърхност и тьмнокафяво оцветяване. Клиниката се доминира от епистаксиси и затруднено носно дишане. За поставяне на диагнозата от значение са образните изследвания, имунохистохимичният анализ и типичната хистологична картина.

Представяме ви клиничен случай на малигнен меланом с локализация в максилоетмоидалния ьгъл на 89-годишен пациент. Болният съобщава за рецидивиращи епистаксиси, нарушено носно дишане и хрема с голяма давност. След направената компютърна аксиална томография (КАТ) и установяване на туморна формация, ангажираща общ носов ход вдясно, максиларен синус, етмоидалнки клетки, проминираща към кухината на назофаринкса, пациентът се приема за оперативно лечение - медиофациална резекция. Резултатът от патолого-хистологичното изследване дава характерната картина на малигнен меланом, поради което пациентьт се насочва за следоперативна химио- и телегаматерапия.

\section{B3}

\section{Сравнение на праговете, измерени с} помощта на класическа аудиометрия

\section{- чист тон и прагове, измерени с помощта на модула DPOAE}

\section{Г. Георгиев}

МБАЛ „Георги Странски“, Катедра „Оториноларингология" - гр. Плевен

Основният фокус е насочен към търсене на корелация между класическата аудиометрия и модула DPOAE (лицензиран). Целта е да се покаже, че е възможно DPOAE да предскаже директно прага за чист тон и да е клинично полезен.

Апаратура за изследване

Методи на изследване:

Tymp: $226 \mathrm{~Hz}$; всички пациенти

PTA: AC; 1; 15; 2, 3, 4KHz; всички пациенти + ВС за пациенти със загуба на слуха

DPOAE Thres: 1; 15; 2, 3, 4 KHz; c FM DPOAE; всички пациенти

DPOAE Thres: 1; 15; 2, 3, 4 KHz; без FM DPOAE; всички пациенти.
Целеви групи: 20 пациенти с нормален слух и 5 пациенти с увреден слух.

Диаграма на получените резултати.

B4

\section{PLUNC протеините: нов поглед върху патогенезата на хроничния риносинуит}

Ю. Хаджиев, Сn. Тодоров, Д. Конов, О. Стоянов, Ст. Йорданов

B5

Ролята на ПЕТ-КТ за дефиниране на мишенните обеми при пациенти с тумори

на глава и шия, подлежащи на високотехнологично льчелечение в Клиника по льчелечение, МБАЛ „Света Марина“ Варна

Хр. Ивановска-Пенева*, Ел. Енчева*, Т. Радева*, Д. Паламудова*, Ем. Барша*, П. Недев**, Н. Сапунджиев**, Г. Илиев**, П. Бочев***, Б. Чаушев ***, Цв. Йорданова***, Ж. Данчева***, Ив. Щерев ${ }^{* * * *}$, Ан. Клисарова $* * *$

*Клиника по льчелечение,

УМБАЛ „, Св. Марина“ - Варна

**Клиника по УНГ,

УМБАЛ „, Св. Марина“ - Варна

***Клиника по нуклеарна медицина и метаболитна терапия,

УМБАЛ „, Св. Марина“ - Варна

****Клиника по медиичиска онкология, УМБАЛ „, Св. Марина“ - Варна

Въведение: Високотехнологичното лъчелечение (ЛЛ) е част от мултидисциплинарното лечение на туморите на глава и шия (ТГШ) както в ранните стадии, така и при локорегионално авансирали тумори с цел органосъхраняване и подобряване на качеството на живот. ПЕТ-КТ при ТГШ намира все по-широко приложение освен за стадиране и за прецизно дефиниране на мишененните обеми (СМО, КМО) в ЛЛ, и проследяване на ефекта от проведено лечение. Цел: Да се проучи за първи път в България ролята и мястото на рутинното приложение на ПЕТ-КТ при планиране и оценка на ефекта от 
дефинитивно високотехнологично ЛЛ за ТГШ. Материали и методи: Включени са всички пациенти с ТГШ, провели дефинитивно ЛЛ в Клиниката по ЛЛ за 2015 г. При всички е проведен ПЕТ-КТ, в позиция за провеждане на облъчването - на плоска маса, с необходимите имобилизиращи устройства. Образите на ПЕТКТ се наслагват с планиращия КТ и на базата на ПЕТ-КТ се дефинират МО. При ТГШ в ранен стадий се прилага самостоятелно ЛЛ, при локорегионално авансирали ТГШ ЛЛ се съчетава с химиотерапия или таргетна терапия. В зависимост от стадия на заболяването и особеностите на отделните пациенти се прилагат 3D или VMAT (Volumetric Modulated Arc Therapy) теxники с образно насочено лъчелечение (IGRT). Техника на едновременен интегриран буст (SIB) се използва при авансирали ТГШ. Оценка ефекта на лечението става на третия месец с контролен локален статус и ПЕТ-КТ.

Резултати: При 40 пациенти с помощта на ПЕТ-КТ се планира 3D ЛЛ при $17,5 \%$ от пациентите, VMAT при $82,5 \%$ и SIB при $60 \%$. ХT и таргетна терапия получиха $70 \%$ от пациентите. ТГШ са разпределени: орофаринкс - $10 \%$; назофаринкс $-8 \%$; хипофаринкс - $12 \%$; ларинкс $35 \%$; устна кухина $-30 \%$; други - 5\%. Стадий: I и II - 30\%; III-IV - 70\%, като плоскоклетъчен - 90\%, други - 10\%. Мъже - 75\%; жени - 25\%. Начален ПЕТ-КТ - 100\% от пациентите.

Заключение: Рутинното приложение на ПЕТ- КТ при планиране на съвремените техники на ЛЛ (VMAT, IGRT, SIB) при ТГШ позволява реализиране на максимална доза в същинския мишенен обем $70 \mathrm{~Gy}$, при по-ниска доза в нискорисковите мишенни обеми (KMO) - 56-60 Gy, като по този начин се намалява дозата в околните здрави тъкани и се подобрява качеството на живот на пациентите при едновременно подобрен локорегионален туморен контрол.

Ключови думи: Планиране лъчелечение, мишенни обеми, ПЕТ-КТ, тумори глава и шия

\section{B6}

\section{Генетични аспекти при отосклероза}

Ор. Стоянов, Сn. Тодоров,

Д. Попова, С. Върбанова
B7

\section{Социално-икономически и демографски аспекти на нарушенията на съня}

М. Милков

Медииински университет

„Проф. д-р Параскев Стоянов“- Варна

Интересьт на световната научна общност към разнообразната проблематика на нарушенията на съня се засили особено много през последното десетилетие. Касае се за широка гама от заболявания и функционални нарушения както при децата, така и при възрастните, характеризиращи се както с различна тежест и продължителност на основните симптоми, така и с трудности при диагностиката и лечението, особено при наличието на придружаващи заболявания на сърдечносъдовата, дихателната, нервната, ендокринната, имунната и храносмилателната система. Постигнатите несьмнени успехи по отношение на прецизната диагностика, консервативното и хирургично лечение на честите нарушения на съня в световен мащаб и в нашата страна все още не са основание за особен оптимизъм. Тези нарушения оказват неблагоприятно влияние върху индивидуалното качество на живот на хората. Безсънието, сънливостта, хъркането и особено - обструктивната сънна апнея представляват нарастващо социално натоварване, изразяващо се както с преки, така и с непреки разходи - за хоспитализации, лекарска помощ, лекарства, институционализирани грижи за болните, от една страна, и намалена производителност, поради инвалидизация и преждевременна смърт, от друга страна. Нарколепсията при децата впоследствие води до редица хронични заболявания с все по-сериозно социално-икономическо натоварване на обществото. Подчертава се ролята на целенасочения скрининг на най-честите нарушения на съня за постепенното намаляване на честотата им и на свързаните с тях последици за здравето на децата и възрастните.

\section{Легенда}

\footnotetext{
*O - оторинология

*P- ринология

*Л - ларингология

*B- вариа
} 